\title{
Praktik Murabahah pada Perbankan Syariah di Kendari
}

\author{
Ummi Kalsum \\ Fakultas Ekonomi dan Bisnis Islam IAIN Kendari \\ kalsumummi75@gmail.com
}

\begin{abstract}
.
This study aims to determine the murabahah financing practices in Islamic banking with a case study in Kendari Branch BMI. This research employs the qualitative research and descriptive explorative research by implementing interview technique, observation and documentation. The collected data then processed and analysed by step reduction, presentation and conclusion. The approach used in this research is normative juridical. The results show that the determination of the law murabahah based on Muslim scholars judgement (ijma') because Muslims have been practicing since the first trading murabahah. Murabahah must not conflict with sharia and regulated in Law No.21 of 2008 concerning Islamic Banking and fatwas DSN-MUI related to murabahah. While based on the results of research in the field of murabahah financing practiced in Kendari Branch BMI is generally in accordance with the provisions set forth by Law No.21 of 2008 concerning Islamic Banking and DSN MUI fatwas both in terms of the parties, the contract murabahah contract pillars, steps murabaha applicable on Islamic banking in Indonesia and some provisions relating to the financing murabaha.
\end{abstract}

\begin{abstract}
Abstrak
Artikel ini bertujuan untuk mengetahui praktek pembiayaan murabahah pada perbankan syariah dengan studi kasus di BMI Cabang Kendari. Hasil penelitian menunjukkan bahwa dalam penetapan hukum murabahah berdasarkan ijma' ulama karena umat Islam telah mempraktekkan jual beli murabahah semenjak dahulu. Murabahah tidak boleh bertentangan dengan syariah dan diatur dalam Undangundang No. 21 Tahun 2008 tentang Perbankan Syariah dan fatwa-fatwa DSN-MUI yang berkaitan dengan murabahah. Sementara berdasarkan hasil penelitian di lapangan pembiayaan murabahah yang dipraktekkan di BMI Cabang Kendari pada umumnya sesuai dengan ketentuan-ketentuan yang diatur oleh Undang-undang No. 21 Tahun 2008 tentang Perbankan Syariah dan fatwa-fatwa DSN MUI baik dari segi syarat para pihak, akad murabahah, rukun akad murabahah, tahapan-tahapan murabahah yang berlaku pada perbankan syariah di Indonesia dan beberapa ketentuan yang berkaitan dengan pembiayaan murabahah.
\end{abstract}

Keywords: murabaha finance, syaria banking, Indonesia, Kendari. 


\section{A. Pendahuluan}

Perbedaan pendapat kategori riba yang diharamkan menurut ulama kontemporer berawal dari penafsiran terhadap ayat-ayat tentang riba yang turun secara bertahap (al-tadrij, evolutif). Menurut Sayyid Qutb yang dirujuk Afzalurrahman, ${ }^{1}$ tahapan pelarangan riba dibagi ke dalam lima tahap. Pertama, Q.S. al-Rum [30]: 39. Kedua, Q.S. al-Nisa [4]: 161. Ketiga, Q.S. Ali Imran [3]: 130: ${ }^{2}$ dalam konteks ayat ini, riba

1 Afzalurrahman, Economic Doctrines of Islam, Vol. III. (Lahore Pakistan: Islamic Publications LTD, 1985), h. 64-65 dan Vol. IV, h. 108-112 dan Ummi Kalsum, Analisis Moneter Islam dalam Sistem Perbankan Ganda di Indonesia. (Jakarta: Ciputat Press, 2012), h. 49-56.

${ }^{2}$ Perbedaan penafsiran terhadap Q.s Ali Imran [3]: 130 memunculkan perbedaan pendapat tentang kategori riba yang diharamkan, yaitu ada dua aliran pemikiran. Aliran pertama, berpendapat bahwa riba yang diharamkan adalah riba yang berlipat ganda (yang presentasenya tinggi), sesuai dengan Q.s Ali Imran [3]: 130 tersebut. Pendapat ini dipelopori oleh Muhammad Asad dan Abdullah Yusuf Ali, yang menafsirkan riba adalah usury yang berarti suku bunga yang lebih dari biasanya atau suku bunga yang tinggi dan bukan interest (bunga yang rendah). Maka dengan merujuk kepada pendapat ini berarti bunga bank tidak termasuk riba yang diharamkan. M. Umer Chapra, The Future of Economics: An Islamic Perspective (Leicester: The Islamic Foundation, 2000), h. 222 dan Muhammad, Kebijakan Moneter dan Fiskal dalam Ekonomi Islam (Jakarta: Salemba Empat, 2002), h. 54-55. Senada dengan pendapat tersebut dikemukakan oleh Muhammad Abduh, Muhammad Rasyid Rida, Abd al-Wahab Khallaf dan Mahmud Shaltut. Mereka berpendapat bahwa riba yang diharamkan adalah riba yang berlipat ganda dan tidak termasuk riba yang kadarnya rendah. Mereka memahami sesuai dengan konteks ayat Q.s Ali Imran [3]: 130 dan menafsirkannya, kata-kata ad'afan mudha'afah adalah sebagai syarat dari kata riba sehingga riba yang diharamkan hanya riba yang berlipat ganda, jika tidak berlipat ganda maka bukan termasuk yang diharamkan. Seorang ulama terkemuka dari PERSIS (Persatuan Islam), A. Hassan, bahkan berpendapat bahwa yang disebut riba adalah bunga dengan suku bunga yang tinggi (ad'afan mudha'afan). Mohammad Hatta, ahli ekonomi terkemuka juga berpendapat bahwa riba adalah bunga pada kredit konsumtif, sementara bunga pada kredit produktif tidak tergolong riba, karena uangnya bermanfaat untuk mendapatkan keuntungan. Sementara mereka yang menghalalkan bunga bank termasuk tokoh Muhammadiyah, Kasman Singodimedjo dan Sjafruddin Prawiranegara, tokoh Masyumi yang pernah menjabat Menteri Keuangan dan Gubernur Bank Sentral, Bank Indonesia pertama. M. Dawam Rahardjo, "Menegakkan Syariat Islam di Bidang Ekonomi”, dalam Bank Islam Analisis Fiqih dan Keuangan (Jakarta: RajaGrafindo Persada, 2004), hal, XIX.

Pendapat yang kedua, menafsirkan bahwa kata-kata adh'afan mudha'afah bukan sebagai syarat dari riba yang diharamkan sehingga mereka berpendapat walaupun riba tersebut tidak berlipat ganda termasuk kategori riba yang diharamkan. Sebab adh'afan mudha'afah bukan dijadikan sebagai syarat tetapi hanya menerangkan bahwa riba yang terjadi pada masa itu atau ciri hutang zaman jahiliah senantiasa bertambah sehingga 
yang diharamkan hanyalah riba yang berlipat ganda. Ayat ini merupakan sumber adanya perbedaan penafsiran yang termasuk kategori riba. Keempat, Q.S. al-Baqarah [2]: 275-276: Allah SWT dengan tegas mengharamkan riba dengan segala bentuknya. Dan kelima, Q.S. alBaqarah [2]: 278: ayat ini menjelaskan secara eksplisit larangan pada tingkat keseluruhan untuk tidak melakukan praktek riba, termasuk sisasisa riba.

Aliran yang melahirkan ide berdirinya bank syariah dan lembaga keuangan syariah adalah aliran kedua yang berpendapat bahwa bunga bank termasuk riba. Para teoritisi perbankan dan fuqaha Muslim yang menyumbangkan teori ini menafsirkan riba sebagai bunga, interest dan keuntungan yang ditambahkan atas pinjaman telah ditentukan sebelumnya. Berdasarkan pandangan ini, berarti setiap penambahan (nominal atau riil) dalam suatu pinjaman yang diberikan kepada kreditur adalah riba. Diterimanya pandangan ini secara otomatis menimbulkan konsekwensi dibutuhkannya lembaga-lembaga keuangan yang kegiatan usahanya berdasarkan selain bunga. Secara otomatis praktik perbankan syariah harus dilaksanakan dengan menggunakan sistem profit and loss sharing principle. Namun, dalam praktiknya bank syariah sejak awal sulit beroperasi berdasarkan profit and loss sharing karena penuh risiko dan tidak pasti.

Perbankan syariah yang ada saat ini bukanlah bank yang murni beroperasi dengan sistem PLS, tetapi bank menggunakan secara ekstensif metode-metode pembiayaan non-PLS ${ }^{3}$, seperti pembiayaan yang berbasis jual beli atau perdagangan mark-up, atau dikenal dengan istilah murabahah. Murabahah merupakan produk pembiayaan yang paling

berlipat ganda. Bukan berarti bunga yang tidak berlipat ganda menjadi halal. Abdullah Saeed, Islamic Banking and Interest, h. 43-44. Quraish Shihab juga menafsirkan adh'afan mudha'afatan pada ayat ini bukan merupakan syarat. Penafsiran ini diperkuat ayat-ayat tentang riba yang turun selanjutnya, Q.s. al-Baqarah [2]: 275-276 dan 278279. M. Quraish Shihab, Tafsir Al-Misbah, Vol. 2 (Jakarta: Lentera Hati, 2008), h. 216217. Ayat-ayat ini secara tegas menyatakan setiap tambahan melebihi pokok pinjaman termasuk riba. Hal ini berlaku bagi setiap bunga baik bersuku bunga rendah maupun tinggi (berlipat ganda), bersifat tetap maupun berubah-ubah bahkan sisa-sisa sekalipun dilarang. Ayat ini secara total mengharamkan riba dalam bentuk apapun. Jadi menurut kelompok ini bunga bank termasuk kategori riba, karena yang disebut riba adalah pembungaan uang oleh mindering yang bunganya sangat tinggi sehingga disebut lintah darat.

${ }^{3}$ Abdullah Saeed, Menyoal Bank Syariah: Kritik atas Interpretasi Bunga Bank Kaum Neo-Revivalis. (Jakarta: Paramadina, 2004), h. 103. 
banyak digunakan oleh perbankan syariah dalam kegiatan usaha. Menurut data yang diperoleh Sutan Remy Sjahdeini dari Ashraf Usmani, bahwa murabahah menduduki porsi $66 \%$ dari semua transaksi investasi bank-bank syariah (Islamic banks) di dunia, sementara di Indonesia, diperkirakan lebih dari $80 \% .{ }^{4}$ Ini membuktikan bahwa murabahah paling banyak dipraktekkan oleh perbankan syariah padahal instrumen utama dalam bisnis Islam itu adalah prinsip profit and loss sharing. Karena dengan prinsip PLS diharapkan sektor riil berkembang sesuai dengan yang diharapkan bukan dengan murabahah yang berbasis jual beli.

Ada sejumlah persoalan yang patut diperhatikan dalam praktik murabahah ini, misalnya, praktik murabahah mempunyai potensi yang mudah disalahgunakan, tidak jarang adanya keluhan bahwa dalam menjual produk murabahah ini bank syariah bagaikan menjual bank konvensional karena murabahah hampir mirip dengan kredit yang ada pada bank konvensional. Misalnya dengan langsung memberikan margin dan tidak mau tahu dengan produk apa yang akan dibeli nasabah bahkan juga tidak melihat langsung properti yang akan dijualnya.

Dengan beberapa masalah di atas, maka penelitian ini bertujuan untuk mendripkripsikan pembiayaan murabahah di Indonesia sesuai dengan Undang Undang No. 21 tahun 2008 dan fatwa-fatwa DSN MUI dan untuk mengetahui bagaimana prakteknya di Bank Muamalat Indonesia Cabang Kendari.

\section{B. Pembiayaan Murabahah Pada Perbankan Syariah}

Definisi murabahah yang ada pada UU No. 21 tahun 2008 belum mencakup syarat-syarat bagi keabsahan suatu akad murabahah. Ada beberapa syarat yang harus dipenuhi pada akad murabahah agar akad murabahah tersebut tidak bertentangan dengan prinsip syariah. Sesuai dengan Pasal 24 ayat (1) huruf a, atau Pasal 24 ayat (2) huruf a, atau Pasal 25 huruf a Undang-undang No. 21 tahun 2008 ditegaskan bahwa bank syariah dilarang melakukan kegiatan usaha yang bertentangan dengan Prinsip Syariah. Dalam fatwa DSN-MUI No 04/DSNMUI/IV/2000 tentang Murabahah juga mengatur hal-hal tersebut pada ketentuan umum pada angka: 1) Bank dan nasabah harus melakukan akad murabahah yang bebas riba. 2) Barang yang diperjualbelikan tidak diharamkan oleh syariat Islam.

\footnotetext{
${ }^{4}$ Sutan Remy Sjahdeini, Perbankan Syariah: Produk-produk dan Aspek-aspek Hukumnya. (Jakarta: Jayakarta Agung Offset, 2010), h. 178.
} 
Oleh karena itu, karena murabahah merupakan salah salah satu bentuk dari $b a$ ' $i$, maka syarat-syarat mengenai keabsahan transaksi $b a$ ' $i$ berlaku juga bagi transaksi murabahah.

1. Berlakunya Syarat-syarat Jual Beli (sale)

Murabahah sebagai bentuk jual beli maka semua syarat yang berlaku bagi sahnya suatu jual beli berlaku pula bagi murabahah. Beberapa syarat pokok jual beli menurut Usmani yang dikutip oleh Ascarya $^{5}$ sebagai berikut: pertama, barang yang akan diperjualbelikan harus ada pada saat transaksi dilakukan. Kedua, barang yang akan diperjualbelikan harus milik penjual. Ketiga, barang yang akan diperjualbelikan harus berada dalam kekuasaan konstruktif (constructive possession $)^{6}$ penjual. Keempat, jual beli harus langsung dan mutlak. ${ }^{7}$ Kelima, objek yang diperjualbelikan harus merupakan barang yang memiliki nilai. Keenam, objek yang diperjualbelikan harus barang yang bukan haram. Ketujuh, objek yang yang diperdagangkan harus dapat diketahui dan dapat diidentifikasi secara spesifik oleh pembeli (jelas spesifikasinya). Kedelapan, penyerahan barang kepada pembeli harus tertentu dan tidak bergantung pada suatu syarat atau kemungkinan. Kesembilan, kepastian harga barang merupakan syarat yang diperlukan agar jual beli sah. Kesepuluh, jual beli harus tanpa syarat (uncondition).

2. Syarat Para Pihak

Syarat para pihak yang terlibat dalam transaksi murabahah harus orang-orang yang memenuhi kualifikasi untuk dapat membuat suatu perjanjian, yaitu cakap hukum dan atas dasar ridha (suka rela) bukan dalam keadaan dipaksa atau terpaksa karena di bawah tekanan.

\section{Akad Murabahah}

Akad murabahah seperti akad-akad muamalah lainnya tidak boleh bertentangan dengan syariah. Sesuai dengan sifat transaksi syariah yang adil (fair) dan transparan, semua syarat dan ketentuan yang berlaku bagi transaksi murabahah harus dirundingkan dan ditentukan di awal

\footnotetext{
${ }^{5}$ Ascarya, Akad \& Produk Bank Syariah, h. 78-81.

${ }^{6}$ Hak milik konstruktif adalah situasi ketika barang secara fisik belum di tangan penjual, tetapi sudah dalam kendalinya, dan semua hak dan kewajiban dari barang tersebut sudah dipindahkan kepadanya, termasuk risiko kerusakan barang.

${ }^{7}$ Berarti jual beli untuk waktu yang akan datang atau jual beli dengan syarat kejadian di waktu yang akan datang tidak sah. Jika para pihak ingin jual beli menjadi efektif, mereka harus melakukannya dengan jual beli baru setelah sampai pada waktu yang akan datang tersebut, atau suatu peristiwa terjadi.
} 
antara bank nasabah sebelum kedua belah pihak menandatangani akad murabahah. Jual beli dalam akad murabahah harus tidak bersyarat (unconditional)dan spesifikasi barang yang dibutuhkan harus dirundingkan dan ditentukan di awal dan dituangkan dalam akad. ${ }^{8}$ Adanya kejelasan margin/mark-up yang akan menjadi keuntungan bank wajib dirundingkan dan ditentukan di muka.

Agar akad murabahah sesuai dengan prinsip syariah harus ada dua transaksi jual beli yang terpisah. Pertama, yaitu transaksi antara pemasok dan bank, ini dilakukan sebelum transaksi yang kedua dilangsungkan yaitu transaksi antara bank dan nasabah. Dua kali transaksi ini tidak mungkin dihindari agar sesuai dengan prinsip syariah. Sebab Remi Syahdeini menambahkan dengan beberapa alasan yang kuat, yaitu: pertama, sebab dalam transaksi murabahah ada dua hubungan hukum yang terpisah yang tidak dapat disatukan dalam satu akad, yaitu (1) hubungan hukum antara pemasok dengan bank, (2) hubungan hukum antara bank dan nasabah. Kedua hubungan hukum tersebut bersifat terpisah maka kedua hubungan hukum tersebut tidak bisa dibuat dalam satu akad. Antara nasabah dengan pemasok tidak ada hubungan hukum sama sekali. Jika nasabah diberi kuasa oleh bank untuk dan atas nama bank berhubungan dan membeli barang yang dibutuhkan langsung dari pemasok bukan berarti timbul hubungan hukum antara nasabah dengan pemasok. Pada kasus ini nasabah bertindak bukan atas namanya sendiri tetapi atas nama bank, ia hanya diberi kuasa.

Alasan kedua, akad jual beli antara bank dan pemasok harus terlebih dahulu dilakukan sebelum terjadinya akad jual beli antara bank dan nasabah. Hak kepemilikan barang dari pemasok kepada bank harus terlebih dahulu berpindah agar bank berhak menjual barang tersebut kepada nasabah berdasarkan akad murabahah. Jika bank menjual barang yang belum dimilikinya maka jual beli tersebut menjadi batal demi hukum (the contract void). ${ }^{9}$

Rukun dari akad murabahah yang harus dipenuhi sebagai berikut;

1. Pelaku akad, yaitu $b a{ }^{\prime} i$ (penjual) adalah pihak yang memiliki barang untuk dijual dan musytari (pembeli) adalah pihak yang memerlukan dan akan membeli barang.

2. Objek akad, yaitu mabi' (barang dagangan) dan tsaman (harga).Tidak semua komoditas dapat dijadikan sebagai objek

\footnotetext{
${ }^{8}$ Sutan Remy Sjahdeini, Perbankan Syariah: Produk-produk...., h. 193.

${ }^{9}$ Sutan Remy Sjahdeini, Perbankan Syariah: Produk-produk...., h. 192.
} 
murabahah. Yang boleh dijadikan sebagai objek murabahah tidak termasuk diharamkan atau yang dilarang, harus bermanfaat, penyerahannya dari penjual ke pembeli dapat dilakukan, merupakan hak milik penuh pihak yang berakad dan sesuai dengan spesifikasi yang telah disepakati sebelumnya.

3. Shighah, yaitu Ijab dan qabul.

\section{Beberapa Ketentuan Berkaitan dengan Pembiayaan Murabahah \\ 1. Harga Barang}

Disyaratkan bahwa harga barang harus disepakati di awal, sebab jika harga tidak dapat dipastikan maka transaksi jual beli tersebut tidak dapat dikatakan sebagai bai' murabahah tetapi bai' musawamah (bargaining). Harga barang tersebut termasuk di dalamnya semua biaya dalam memperoleh barang tersebut atau dengan kata lain semua modalnya harus dapat dipastikan.

\section{Potongan Harga Barang}

Bank dapat memberikan potongan harga (muqasah) dalam pembiayaan murabahah dengan besaran yang wajar tanpa diperjanjikan di muka. Dalam praktik, potongan harga tersebut diberikan oleh bank apabila nasabah melunasi utang murabahahnya tepat waktu atau lebih awal dari waktu yang disepakati untuk melunasi pembayarannya.

Ketentuan potongan harga (diskon) terhadap barang dari suplier (pemasok) jika diberikan sebelum ditandatangi perjanjian atau akad antara nasabah dan bank, maka potongan harga (diskon) merupakan hak nasabah. Tetapi jika diskonnya diberikan setelah akad dilakukan, maka pembagian potongan harga tersebut dilakukan berdasarkan perjanjian yang dibuat antara bank dan nasabah yang dimuat dalam akad. Hal ini sesuai dengan Fatwa DSN-MUI No. 16/DSN-MUI/IX/2000 tentang Diskon dalam Murabahah.

Remi Syahdeini berpendapat, ${ }^{10}$ bahwa dalam pembiayaan murabahah diperkenankan memberikan potongan harga/rabat (rabate) asalkan tidak diperjanjikan atau disyaratkan sebelumnya pada akad murabahah. Oleh karena itu jika nasabah melunasi hutangnya lebih awal dari jadwal pembayaran yang seharusnya dan sebelumnya tidak ada komitmen dari pihak bank untuk memberikan diskon atau rabat maka kebijakan apakah memberi diskon/rabat atau tidak memberikannya

${ }^{10}$ Sutan Remy Sjahdeini, Perbankan Syariah: Produk-produk...., h. 200. 
kepada nasabah tersebut diserahkan kepada bank untuk memutuskannya. Hal ini diatur dalam Fatwa DSN-MUI No. 23/DSN-MUI/III/2002 tentang Potongan Pelunasan dalam Murabahah dan Fatwa DSN-MUI No. 46/DSN-MUI/II/2005 tentang Potongan Tagihan Murabahah (Khashm fi al-Murabahah) memberikan ketentuan sebagai berikut:

a. Lembaga Keuangan Syariah (LKS) boleh memberikan potongan dari total kewajiban pembayaran kepada nasabah dalam transaksi (akad) murabahah yang telah melakukan kewajiban pembayaran cicilannya dengan tepat waktu dan nasabah mengalami penurunan kemampuan pembayaran.

b. Besar potongan sebagaimana dimaksud di atas diserahkan kepada kebijakan LKS.

c. Pemberian potongan tidak boleh diperjanjikan dalam akad.

Fatwa di atas mengandung makna bahwa tidak ada larangan bagi lembaga keuangan syariah (LKS) untuk memberikan keringanan harga atau diskon harga kepada nasabah sebagai hadiah karena telah melaksanakan kewajibannya untuk membayar cicilan dengan tepat waktu atau sebagai pemberian keringanan bagi nasabah yang menurun kemampuannya untuk melaksanakan kewajiban pembayaran yang terutang kepada bank. Potongan juga bisa diberikan kepada nasabah yang dapat melaksanakan kewajiban pembayaran lebih dini dari jatuh tempo jadwal kewajiban pembayaran tersebut (rebate earlier paymnt).

Karena tidak ada larangan bagi LKS untuk memberikan potongan harga kepada nasabah maka LKS diperkenankan untuk mempraktekkannya dengan memberikan potongan harga bagi nasabah yang telah melunasi hutangnya tepat waktu atau malah menyelesaikan kewajibannya lebih awal dari waktu yang dijadwalkan. Hal ini mengingat adanya persaingan dengan bank konvensional yang telah mempraktekkanya dan menjadikannya sebagai sebuah strategi pemasaran yang sudah lazim. Namun bagi LKS harus mempraktikkan harus sesuai syariah dengan syarat tidak disyaratkan (tidak ada komitmen) ketika akad.

\section{Uang Muka dalam Murabahah}

Ketentuan masalah uang muka (urbun) pada pembiayaan murabahah dijelaskan Fatwa DSN-MUI No. 13/DSN-MUI/IX/2000 tentang Uang Muka dalam Murabahah menentukan bank dapat meminta uang muka (urbun) kepada nasabah jika kedua belah pihak sepakat. Jika akad murabahah tetap dilaksanakan, maka uang mukanya tersebut 
menjadi pelunasan piutang murabahah dari bank. Tetapi jika akad murabahah tidak jadi dilaksanakan maka urbun wajib dikembalikan bank kepada nasabah setelah nilai uang muka tersebut dikurangi dengan biayabiaya dan kerugian bank sepanjang ketentuan pengurangan nilai uang muka tersebut dengan biaya-biaya dan kerugian bank tersebut telah disepakati di muka oleh kedua belah pihak. Jika nilai urbun lebih kecil dari biaya-biaya dan biaya-biaya dan kerugian bank, maka bank dapat meminta tambahan atas kekurangan nilai urbun tersebut dari nasabah.

\section{Mark-up/Margin keuntungan dalam Murabahah}

Mark-up/margin dalam pembiayaan murabahah merupakan hak penjual yang harus dibicarakan dengan jelas agar tidak mengundang perselisihan. Harga jual objek transaksi dari bank kepada nasabah dalam pembiayaan murabahah adalah harga beli bank dari suplier (pemasok) ditambah dengan mark-up/margin (keuntungan) dan biaya-biaya yang timbul dari proses pembeliaan barang tersebut. Margin juga merupakan bagian dari harga, karena harga pokok plus margin merupakan harga jual, dan mengetahui harga jual merupakan syarat sahnya jual beli. Dalam proses pembiayaan murabahah harus bersifat fair dan tansparan baik dalam masalah harga beli barang (cost price) harus diungkapkan oleh bank kepada nasabah. Dalam hal mark-up/margin juga harus disepakati di muka sebelum kedua belah pihak menandatangani akad murabahah.

Mark-up atau margin bisa ditentukan baik dalam bentuk suatu lump sum atau dengan menetapkan rasio tertentu terhadap harga beli bank. Margin tersebut hanya boleh ditetapkan satu kali untuk satu transaksi pembelian barang oleh nasabah. Tidak boleh ditetapkan atas nasabah membayar margin tersebut setiap jangka waktu tertentu, misalnya untuk bulan tertentu (bulan Mei). Jika diperjanjikan demikian maka mark- up/margin tersebut tidak ubahnya dengan sistem bunga yang dilarang dalam Islam.

\section{Jaminan}

Meminta jaminan atas hutang dalam Islam pada dasarnya bukan sesuatu yang tercela. ${ }^{11}$ Jaminan adalah salah satu cara untuk memastikan bahwa hak-hak kreditur tetap terjaga (tidak akan dihilangkan), dan untuk menghindarkan diri dari memakan harta orang dengan cara yang batil, Q.s al-Nisa [4]: 29 .

${ }^{11}$ Q.S Al-Baqarah [2]: 283. 
Keberadaan jaminan (rahn) dalam pembiayaan murabahah dibolehkan sebagaimana diatur dalam Fatwa DSN No. 04/DSNMUI/IV/2000 tentang murabahah, tujuannya agar nasabah serius dalam pesanannya. Bank bisa meminta nasabah untuk menyediakan jaminan yang dapat dipegang. Karena barang yang dijual bank kepada nasabah sejak akad sudah menjadi milik nasabah dan dapat dibalik nama atas nama nasabah yang bersangkutan, maka barang yang dibiayai dengan fasilitas pembiayaan berdasarkan akad pembiayaan murabahah tersebut merupakan agunan pokok yang dapat diikat sesuai dengan ketentuan yang berlaku. $^{12}$ Jaminan bisa berupa agunan barang maupun penjaminan/penanggunan oleh orang atau korporasi. Sementara di Indonesia, agunan dapat berupa hak-hak jaminan atas barang seperti hak tanggungan, hipotik, gadai dan fidusia. Bila merujuk kepada ketentuan KUH Perdata, jaminan yang berupa penjaminan/penangungan adalah penjaminan/penanggungan sebagaimana diatur pada pasal 1820 sampai dengan Pasal 1850 KUH Perdata.

Dalam praktek pada perbankan syariah, biasanya bank syariah mengikat barang yang diperjualbelikan itu (objek murabahah) dijadikan sebagai agunan bagi pelunasan kewajiban nasabah. ${ }^{13}$ Pada kasus ini dalam istilah perbankan disebut agunan pokok. Pengikatan agunan tersebut dilakukan bank sesuai dengan ketentuan perundang-undangan yang berlaku.

Selain barang yang diperjualbelikan, bank juga dibolehkan untuk meminta agunan yang bukan berupa barang yang dibiayai dari nasabah berupa harta kekayaan lain milik nasabah atau harta milik pihak ketiga. Agunan tersebut disebut agunan tambahan. Bank juga tidak dilarang untuk menerima atau meminta jaminan lain misalnya berupa penanggungan (guarantee) oleh penganggung (guarantor) atas pelaksanaan kewajiban nasabah. Penanggung tersebut dapat berupa orang perorangan (personal guarantor) maupun berupa korporasi (corporate guarantor) dan dapat juga meminta dari pihak ketiga. Jika terjadi cidera janji atas pembayaran oleh nasabah, maka bank dapat meminta agar penjamin/penanggung untuk melunasi tagihannya.

Berkaitan dengan penjaminan/penanggungan tersebut, menurut Usmani terdapat dua masalah: pertama, penjamin/penanggung

\footnotetext{
${ }^{12}$ Wangsa Widjaja Z., Pembiaayaan Bank Syariah. (Jakarta: Gramedia Pustaka Utama, 2012), h. 201.

${ }^{13}$ Sutan Remy Sjahdeini, Perbankan Syariah: Produk-produk......, h. 199.
} 
(guarantor) tidak dapat meminta atau meminta fee kepada nasabah. Sebab jika seseorang membebankan fee untuk keperluan pemberian pinjamanan termasuk kategori riba. Kedua, penjamin/penanggung dapat membebankan biaya (expenses) untuk keperluan dokumentasi penjaminan tersebut. Namun bagi Remi Syahdeini bahwa pembebanan fee oleh penjamin/penanggung bukan sesuatu yang dilarang (bukan termasuk riba). Ini merupakan kebijakan dalam upaya pengembangan perbankan syariah, jadi pembenanan tersebut dimungkinkan. ${ }^{14}$ Bank juga dimungkinkan untuk meminta agar nasabah menandatangani suatu promissory note atau suatu bill of exchange. Sebab menurut Taqi Usmani, pemberian promissory note atau bill of exchange hanya boleh dilakukan apabila jual beli barang yang sesungguhnya telah terjadi.

\section{Ketentuan Perpajakan dalam Pembiayaan Murabahah}

Merujuk kepada moda pembiayaan murabahah yang mengandung dua kali transaksi jual beli, yaitu pertama, transaksi (akad) antara pemasok dengan bank dan kedua, transaksi antara bank dengan nasabah. Hal ini sesuai dengan pandangan Direktorat Jenderal Pajak dan Fatwa DSN-MUI No. 04/DSN-MUI/IV/2000 Tentang Murabahah. Namun sejak tanggal 1 April 2010, ketentuan mengenai dibebankannya dua kali Pajak Pertambahan Nilai (PPN) pada transaksi murabahah yang terdiri atas dua transaksi jual beli, yaitu jual beli antara pemasok barang dengan bank dan transaksi jual beli antara bank dan nasabah telah diubah menjadi hanya dibebankan satu kali PPN. Perubahan ketentuan tersebut merupakan yang positif bagi perkembangan perbankan syariah ke depan di Indonesia.

\section{Cara Pembayaran Harga Barang}

Pembayaran harga barang oleh nasabah kepada bank dapat dilakukan secara cicilan (taqsith/installment) maupun secara sekaligus (muajjal/lump sum) pada waktu yang telah ditentukan. Tetapi pada umumnya sistem pembayaran dalam pembiayaan murabahah pada LKS dilakukan secara cicilan dalam kurun waktu yang disepakati antara nasabah dan bank.

\footnotetext{
${ }^{14}$ Sutan Remy Sjahdeini, Perbankan Syariah: Produk-produk....., h. 200.
} 


\section{Cidera Janji}

Cara pembayaran pada pembiayaan murabahah harus dilunasi pada waktu tertentu, tidak jauh berbeda dengan pembiayaan berdasarkan suku bunga tetap. Dalam kedua pembiayaan tersebut, pembiayaan adalah hutang dan biaya pembiayaannya adalah bunga dan bagi murabahah adalah laba. Perbedaan yang sangat signifikan antara keduanya adalah jika debitur gagal melunasi hutang pada waktu yang telah ditentukan. Pinjaman dengan bunga pada umumnya menimbulkan sanksi bunga tambahan jika hutang tidak dilunasi pada waktu jatuh tempo. Sementara pada bank syariah, jika nasabah cidera janjinya karena faktor tidak mampu melaksanakan kewajibannya untuk membayar hutangnya, menurut prinsip syariah bank syariah tidak dilarang bahkan diwajibkan untuk memberikan toleransi atau kelonggaran (Q.S. Al-Baqarah [2]: 280).

Penundaan semacam ini harus diberikan tanpa ada penambahan beban tambahan kepada debitur. Hanya saja dalam praktiknya, perbankan syariah mempersempit makna perintah Al-Qur'an tersebut. Penerapan perintah tersebut secara umum merupakan celah potensial bagi debitur yang mungkin lalai untuk melunasi hutangnya padahal mereka mampu melunasinya. Untuk menutup penyalahgunaan celah potensial tersebut, Dewan Syariah mengadopsi konsep denda terhadap mereka yang tidak melunasi utangnya tepat waktu, khususnya jika debitur mampu melunasinya. Menurut Abdullah Saeed makna definitif tidak mampu membayar sulit untuk ditentukan dalam konteks ini, karena bank syariah umumnya sejak awal kontrak murabahah telah memastikan bahwa dana-dana yang mereka pinjamkan akan cukup aman dan dijamin terlindungi dari segala risiko kegagalan atau penundaan pembayaran. Ini menjamin pembayaran harga murabahah plus mark-up pada bank syariah dan di samping itu suatu denda atas keterlambatan pembayaran dapat dijatuhkan kepada nasabah, dan nasabah wajib mematuhinya. ${ }^{15}$

Lebih spesifik menurut Ashraf Usmani yang dikemukakan Remi Syahdeini, ${ }^{16}$ bagi nasabah yang tidak jujur atau yang tidak beriktikad baik yaitu nasabah yang dengan sengaja tidak melunasi harga barang yang telah dibelinya maka bank dapat mewajibkan untuk membayar kompensasi atas kerugian yang diderita bank.

\footnotetext{
${ }^{15}$ Abdullah Saeed, Menyoal Bank Syariah, h.139-140.

${ }^{16}$ Abdullah Saeed, Menyoal Bank Syariah, h. 203.
} 
Fatwa Dewan Syariah Nasional MUI No. 17/DSN-MUI/IX/2000 tentang Sanksi Atas Nasabah Mampu Yang Menunda-nunda Pembayaran, menentukan bahwa nasabah mampu yang menunda-nunda pembayaran dan/atau tidak mempunyai kemauan dan itikad baik untuk membayar hutangnya boleh dikenakan sanksi oleh LKS, tetapi nasabah yang tidak/belum mampu membayar disebabkan force majeur tidak boleh dikenakan sanksi. Jadi bagi nasabah yang mampu tetapi menundanunda pembayaran atau tidak mempunyai itikad baik untuk membayar hutangnya maka bisa dikenakan sanksi yang bertujuan agar nasabah lebih disiplin.

\section{Beberapa Ketentuan Pada Pembiayaan Murabahah di Bank Muamalat Indonesia (BMI) Cabang Kendari}

Bank syariah dalam operasionalnya harus sesuai dengan prinsip syariah. Demikian juga BMI, yang ditegaskan pada klausul akad pembiayaan murabahah. Para pihak yang melakukan transaksi murabahah pada BMI Cabang Kendari yaitu nasabah dan bank sepakat melaksanakan akad murabahah menurut ketentuan syariah dan peraturan perundang-undangan yang berlaku di Indonesia.

Beberapa ketentuan yang harus dipenuhi dalam murabahah secara umum telah dipaparkan di atas, sementara dalam prakteknya sebagai berikut;

\section{Harga Barang}

Bank Muamalat mengadakan barang yang dibutuhkan dan menjualnya kepada nasabah dengan harga sesuai kesepakatan yang telah ditetapkan. Pada BMI Cabang Kendari ${ }^{17}$ disyaratkan bahwa harga barang harus disepakati di awal, jika harga barang tidak ada kesepakatan dan tidak dapat dipastikan maka jual beli tersebut batal. Sebab jika harga tidak dapat dipastikan maka transaksi jual beli tersebut tidak dapat dikatakan sebagai bai' murabahah tetapi bai' musawamah (bargaining). Harga barang tersebut termasuk di dalamnya semua biaya dalam memperoleh barang tersebut atau dengan kata lain semua modalnya harus dapat dipastikan. Harga jual adalah harga beli bank dari produsen/pemasok ditambah dengan keuntungan (margin/mark-up). Kedua pihak harus menyepakati harga jual dan jangka waktu pembayaran. Hal ini dijelaskan secara detail sebagai salah satu klausul

\footnotetext{
${ }^{17}$ Sudarman Muhajir, (Marketing Konsumer), Wawancara tanggal 6 Juli 2015.
} 
pada akad pembiayaan murabahah pada pasal 4 tentang ketentuan pokok akad.

Pihak BMI Cabang Kendari $^{18}$ juga menguatkan dari analisa tersebut bahwa dalam pembiayaan murabahah, tersebut harga barang yang dijadikan sebagai objek transaksi dijelaskan pada akad dan dicantumkan sebagai salah satu klausul pada akad murabahah tersebut.

\section{Potongan Harga Barang}

Masalah potongan harga barang (diskon) pada Bank Muamalat Indonesia (BMI) Kendari ${ }^{19}$ mengacu kepada fatwa-fatwa DSN- MUI, secara garis besar ada dua kasus, yaitu:

Pertama, BMI Cabang Kendari memberikan potongan harga (muqasah) dalam pembiayaan murabahah dengan besaran yang wajar tetapi tanpa diperjanjikan di muka. ${ }^{20}$ Potongan harga tersebut diberikan oleh bank apabila nasabah melunasi utang murabahahnya lebih awal daripada jangka waktu akad pembiayaan. Hal ini diatur Fatwa DSN-MUI No. 23/DSN-MUI/III/2002 tentang Potongan Pelunasan dalam Murabahah: Fatwa DSN-MUI No. 23/DSN-MUI/III/2002 tentang Potongan Pelunasan dalam Murabahah: (1) Jika nasabah dalam transaksi Murabahah melakukan pelunasan pembayaran tepat waktu atau lebih cepat dari waktu yang telah disepakati, LKS boleh memberikan potongan dari kewajiban pembayaran tersebut, dengan syarat tidak diperjanjikan dalam akad.

Kedua, BMI menentukan dengan merujuk fatwa DSN-MUI No. 16/DSN-MUI/IX/2000 tentang Diskon dalam Murabahah angka 3, 4 dan 5: "(3) Jika dalam jual beli murabahah LKS mendapat diskon dari suplier, harga sebenarnya adalah harga setelah diskon; karena itu, diskon adalah hak nasabah". (4) Jika pemberian diskon terjadi setelah akad, pembagian diskon tersebut di lakukan berdasarkan perjanjian (persetujuan) yang dimuat dalam akad. (5) Dalam akad, pembagian diskon setelah akad hendaklah diperjanjikan dan ditandatangani.

Kemudian jika diskon diberikan suplier (pemasok) sebelum akad (transaksi) ditandatangi antara nasabah dan bank maka diskon tersebut diberikan bank kepada nasabah karena merupakan hak nasabah dan dihitung menjadi pengurangan harga jual atau harga barang. Tetapi jika

\footnotetext{
${ }^{18}$ Sudarman Muhajir, Wawancara pada tanggal 6 Juli 2015.

${ }^{19}$ Sudarman Muhajir, Wawancara pada tanggal 6 Juli 2015.

${ }^{20}$ Sudarman Muhajir, Wawancara pada tanggal 6 Juli 2015.
} 
diskonnya diberikan setelah akad dilakukan, maka pembagian potongan harga tersebut dilakukan berdasarkan perjanjian yang dibuat antara bank dan nasabah. Selain diatur pada fatwa DSN-MUI No.16/DSNMUI/IX/2000 tentang Diskon dalam Murabahah, hal ini juga dijelaskan pada klausul akad pembiayaan murabahah pasal 8 tentang diskon dari pemasok No.1 dan 2.

Fatwa di atas mengandung makna bahwa tidak ada larangan bagi LKS untuk memberikan keringanan harga atau diskon harga kepada nasabah sebagai hadiah karena telah melaksanakan kewajibannya untuk membayar cicilan dengan tepat waktu atau sebagai pemberian keringanan bagi nasabah yang menurun kemampuannya untuk melaksanakan kewajiban pembayaran yang terutang kepada bank. Potongan juga bisa diberikan kepada nasabah yang dapat melaksanakan kewajiban pembayaran lebih dini dari jatuh tempo jadwal kewajiban pembayaran tersebut (rebate earlier paymnt).

Karena tidak ada larangan bagi LKS untuk memberikan potongan harga kepada nasabah maka LKS diperkenankan untuk mempraktekkannya dengan memberikan potongan harga bagi nasabah yang telah melunasi hutangnya tepat waktu atau malah menyelesaikan kewajibannya lebih awal dari waktu yang dijadwalkan. Hal ini mengingat adanya persaingan dengan bank konvensional yang telah mempraktekkanya dan menjadikannya sebagai sebuah strategi pemasaran yang sudah lazim. Namun bagi LKS harus mempraktikkan harus sesuai syariah dengan syarat tidak disyaratkan (tidak ada komitmen) ketika akad.

\section{Uang Muka dalam Murabahah}

Bank Mualamat Indonesia (BMI) Cabang Kendari dalam praktek pembiayaan murabahah meminta uang muka (urbun) kepada nasabah sebagai tanda keseriusan nasabah. Merujuk kepada kepada ketentuan yang terdapat pada Fatwa DSN-MUI No. 13/DSN-MUI/IX/2000 tentang Uang Muka dalam Murabahah yang ketentuannya sudah dijelaskan pada bab dua, ditegaskan bahwa tidak ada larangan bagi Lembaga Keuangan Syariah (LKS) untuk meminta uang muka kepada nasabah.

Uang muka yang ditentukan BMI Cabang Kendari terhadap nasabah pada pembiayaan KPR mengacu kepada peraturan Bank Indonesia yakni $30 \%$ dari total biaya pembiayaan dan $70 \%$ yang dibantu oleh BMI. Sementara pembiayaan selain KPR, seperti untuk renovasi rumah atau pembelian bahan bangunan atau pembelian alat-alat 
elektronik BMI Cabang Kendari menerapkan tanpa meminta uang muka, BMI murni membiayai sepenuhnya. ${ }^{21}$

Jika akad pembiayaan murabahah tetap dilaksanakan, maka uang mukanya tersebut menjadi pelunasan piutang murabahah dari bank. Tetapi jika akad murabahah tidak jadi dilaksanakan maka urbun akan dikembalikan Bank Muamalat kepada nasabah setelah nilai uang muka tersebut dikurangi dengan biaya-biaya dan kerugian bank sepanjang ketentuan pengurangan nilai uang muka tersebut dengan biaya-biaya dan kerugian bank tersebut telah disepakati di muka oleh kedua belah pihak. Jika nilai uang mukanya lebih kecil dari biaya-biaya dan kerugian bank, maka bank dapat meminta tambahan atas kekurangan nilai urbun tersebut dari nasabah. Pihak BMI Cabang Kendari ${ }^{22}$ juga mengatakan bahwa dalam pembiayaan murabahah uang muka juga dijelaskan pada akad yang dicantumkan sebagai salah satu klausul pada akad murabahah, tertera pada pasal 4 tentang Ketentuan Pokok Akad, karena BMI mengedepankan transparansi dan fair dalam prosesnya.

\section{Mark-up/Margin dalam Murabahah}

Margin adalah selisih harga jual dengan harga perolehan yang menjadi keuntungan bank atas terjadinya jual beli yang disepakati oleh bank dan nasabah sesuai akad. BMI Cabang Kendari dalam hal nilai nominal harga barang yang harus dibayar oleh nasabah dijelaskan dengan detail. Termasuk mark-up/margin-nya dalam pembiayaan murabahah harus diketahui dan disetujui nasabah.

Mark-up/margin dalam pembiayaan murabahah merupakan hak penjual yaitu BMI tetapi dibicarakan dengan nasabah agar jelas dan tidak mengundang perselisihan di kemudian. Berdasarkan analisa terhadap lembaran akad antara nasabah dan bank pada pasal 4 tentang ketentuan pokok akad dijelaskan bahwa harga jual objek transaksi dari bank kepada nasabah dalam pembiayaan murabahah adalah harga beli bank dari suplier (pemasok) ditambah dengan mark-up/margin (keuntungan) dan biaya-biaya yang timbul dari proses pembeliaan barang tersebut. Margin juga merupakan bagian dari harga, karena harga pokok plus margin merupakan harga jual, dan mengetahui harga jual merupakan syarat sahnya jual beli. Untuk itu proses pembiayaan murabahah bersifat tansparan dan jelas baik dalam masalah harga beli barang (cost price),

\footnotetext{
${ }^{21}$ Sudarman Muhajir, Wawancara pada tanggal 6 Juli 2015.

${ }^{22}$ Sudarman Muhajir, Wawancara pada tanggal 6 Juli 2015.
} 
margin/mark-up diungkapkan oleh bank kepada nasabah. Dalam hal mark-up/margin juga harus disepakati di muka sebelum kedua belah pihak menandatangani akad murabahah.

Analisa ini diperkuat dari petikan hasil wawancara penulis dengan pihak Bank Muamalat Indonesia (BMI) Cabang Kendari dalam menetapkan marginnya hanya satu kali untuk satu transaksi pembelian barang oleh nasabah sesuai dengan ketentuan yang ada dan bersifat terbuka dan transparan. Karena tidak boleh menetapkan margin terhadap nasabah setiap jangka waktu tertentu, misalnya untuk bulan tertentu (bulan Mei).

"Marjin dalam pembiayaan murabahah pada BMI ditetapkan ketika akad dan ditetapkan hanya satu kali bersifat terbuka dan jelas oleh nasabah dan dicantumkan pada klausul akad pembiayaan murabahah tersebut. $^{24}$

Dengan ketentuan margin/mark-up atau harga lebih yang ditambahkan pada harga pokok objek murabahah ditetapkan hanya satu kali yang diterapkan BMI maka angsurannya akan bersifat tetap tidak akan naik mengikuti fluktuasi suku bunga.

Faktor-faktor yang mempengaruhi perbankan syariah di Indonesia termasuk Bank Muamalat Indonesia (BMI) Cabang Kendari dalam menentukan mark up/marginnya, sebagai berikut: ${ }^{25}$ pembiayaan murabahah berdasarkan tingkat keuntungan keuntungan riil yang diinginkan, inflasi, suku bunga, kebijakan moneter, suku bunga luar negeri dan marketabilitas barang-barang murabahah serta tingkat laba yang diharapkan dari barang tersebut. ${ }^{26}$ Sebab berdasarkan wawancara dengan pihak BMI Cabang Kendari sendiri, faktor-faktor yang mempengaruhi dalam penentuan suku bunga. ${ }^{27}$ Konsekwensi dari kesamaan faktor ini, suku bunga dan mark-up dalam murabahah untuk dana-dana yang disalurkan yang sebanding akan sama. Mark-up/margin juga dipengaruhi oleh faktor tenggang waktunya, mark-up akan cenderung semakin tinggi jika tenggang waktu yang diinginkan nasabah semakin lama.

\footnotetext{
${ }^{23}$ Sudarman Muhajir, Wawancara pada tanggal 6 Juli 2015.

${ }^{24}$ Sudarman Muhajir, Wawancara pada tanggal 6 Juli 2015.

${ }^{25}$ Sudarman Muhajir, Wawancara pada tanggal 6 Juli 2015.

${ }^{26}$ Abdullah Saeed, Menyoal Bank Syariah: Kritik atas Interpretasi Bunga Bank Kaum Neo-Revivalis (Jakarta: Paramadina, 2004), h. 129.

${ }^{27}$ Sudarman Muhajir, Wawancara pada tanggal 6 Juli 2015.
} 


\section{Jaminan}

Jaminan adalah agunan dan/atau segala sesuatu yang berwujud maupun tidak berwujud untuk mendukung keyakinan bank atas kemampuan dan kesanggupan nasabah untuk melunasi kewajiban nasabah sesuai akad, Pasal 1 No. (8) akad pembiayaan murabahah. Sementara agunan adalah barang bergerak maupun barang tidak bergerak yang diserahkan oleh pemilik agunan kepada bank guna menjamin pelunasan kewajiban nasabah. Pasal 1 No. (1) akad pembiayaan murabahah BMI.

Perbankan syariah dalam operasionalnya menerapkan prudential principle untuk menjamin terjaganya aset perbankan syariah meminta jaminan atau agunan dalam pembiayaan murabahah bertujuan untuk menjamin agar seluruh kewajiban nasabah hingga lunas dan tepat waktu. Pada klausul akad pembiayaan murabahah juga dicantumkan tentang jaminan dan agunan yaitu pada Pasal 11 tentang Pemberian Jaminan dan Agunan. Serta jaminan-jaminan lain yang mungkin disyaratkan oleh bank dikemudian hari apabila diperlukan oleh bank dalam bentuk dan pengikatan yang akan ditetapkan oleh bank. Apabila menurut pendapat bank nilai dari jaminan tidak cukup untuk menjamin kewajiban nasabah kepada bank, maka atas permintaan pertama dari bank, nasabah wajib menambah agunan lainnya yang disetujui bank.

Barang yang dijadikan sebagai jaminan oleh perbankan syariah di Indonesia termasuk BMI Cabang Kendari, mereka mengikat barang yang diperjualbelikan itu (objek murabahah) dijadikan sebagai agunan bagi pelunasan kewajiban nasabah (jaminan hutang), agunan pokok. ${ }^{28}$ Selain barang yang diperjualbelikan, bank juga dibolehkan untuk meminta agunan yang bukan berupa barang yang dibiayai dari nasabah berupa harta kekayaan lain milik nasabah atau harta milik pihak ketiga. Agunan tersebut disebut agunan tambahan. ${ }^{29}$ Bank juga tidak dilarang untuk menerima atau meminta jaminan lain misalnya berupa penanggungan (guarantee) oleh penganggung (guarantor) atas pelaksanaan kewajiban nasabah. Penanggung tersebut dapat berupa orang perorangan (personal guarantor) maupun berupa korporasi (corporate guarantor) dan dapat juga meminta dari pihak ketiga. Jika terjadi cidera janji atas pembayaran

\footnotetext{
${ }^{28}$ Sudarman Muhajir, Wawancara pada tanggal 6 Juli 2015.

${ }^{29}$ Sudarman Muhajir, Wawancara pada tanggal 6 Juli 2015.
} 
oleh nasabah, maka bank dapat meminta agar penjamin/penanggung untuk melunasi tagihannya.

\section{Ketentuan Perpajakan dalam Pembiayaan Murabahah}

Sejak tanggal 1 April 2010, ketentuan mengenai dibebankannya dua kali Pajak Pertambahan Nilai (PPN) pada transaksi murabahah yang terdiri atas dua transaksi jual beli, yaitu jual beli antara pemasok barang dengan bank dan transaksi jual beli antara bank dan nasabah telah diubah menjadi hanya dibebankan satu kali PPN.

\section{Cara Pembayaran Harga Barang}

Pembayaran harga barang oleh nasabah kepada bank dapat dilakukan secara cicilan (taqsith/installment) maupun secara sekaligus (muajjal/lump sum) pada waktu yang telah ditentukan. Tetapi umumnya pada pembiayaan murabahah dilakukan secara cicilan. Hal ini secara spesifik dijelaskan pada akad pembiayaan murabahah pada Pasal 4 tentang ketentuan pokok akad huruf (j) jumlah angsuran perbulan dan tanggal pembayarannya sesuai dengan jadwal terlampir. Dan pada huruf (k) denda tunggakan. Jumlah nominal pada masing-masing huruf ini semuanya disebutkan secara spesifik.

Lebih lanjut diatur pada klausul akad pembiayaan murabahah Pasal 7 tentang Tata Cara Pembayaran Kewajiban dijelaskan secara spesifik secara teknis cara pembayaran angsuran kewajiban nasabah (hutang nasabah).

\section{Cidera Janji}

Bank Muamalat Indonesia dalam masalah ini mengacu kepada Fatwa Dewan Syariah Nasional MUI ${ }^{30}$ No. 17/DSN-MUI/IX/2000 tentang Sanksi Atas Nasabah Mampu Yang Menunda-nunda Pembayaran. Bagi nasabah yang cidera janji/lalai/pelanggaran janji kategorinya dijelaskan pada klausul akad pembiaayaan murabahah Pasal 13 tentang Cidera Janji/Kelalaian/Pelanggaran dan selanjutnya akibat cidera janji,

Jadi akibat cidera janji maka bank boleh mengambil tindakan dengan menjual agunan yang diberikan oleh nasabah. Hasil penjualan dari agunan tersebut digunakan untuk pembayaran hutang

30 Joni Nanang Harundana, Wawancara pada tanggal 6 Juli 2015. Dan Sudarman Muhajir, Wawancara pada tanggal 6 Juli 2015. 
nasabah kepada bank, jika ada sisa akan dikembalikan kepada nasabah atau penjamin sebagai pemilik harta benda yang dijaminkan kepada bank. Dan sebaliknya jika hasil penjualan agunan tersebut tidak cukup untuk melunasi hutang nasabah maka kekurangan tersebut tetap menjadi kewajiban nasabah kepada bank untuk melunasinya.

\section{E. Kesimpulan}

Hasil penelitian menunjukkan bahwa dalam penetapan hukum murabahah berdasarkan ijma ulama karena umat Islam telah mempraktekkan jual beli murabahah semenjak dahulu. Demikian juga Imam Malik dan Imam Syafi'i menyatakan jual beli murabahah halal, namun mereka tidak memperkuat pendapatnya dengan satu hadispun. Imam Malik hanya merujuk kepada apa yang dipraktikkan penduduk Madinah. Sementara Nejatullah Siddiqi menyarankan agar murabahah tidak dipraktikkan di perbankan Islam. Murabahah tidak boleh bertentangan dengan syariah dan diatur dalam Undang-undang No. 21 Tahun 2008 tentang Perbankan Syariah dan fatwa-fatwa DSN-MUI yang berkaitan dengan murabahah. Sementara berdasarkan hasil penelitian di lapangan pembiayaan murabahah yang dipraktekkan di BMI Cabang Kendari pada umumnya sesuai dengan ketentuan-ketentuan yang diatur oleh Undang-undang No. 21 Tahun 2008 tentang Perbankan Syariah dan fatwa-fatwa DSN MUI baik dari segi syarat para pihak, akad murabahah, rukun akad murabahah, tahapan-tahapan murabahah yang berlaku pada perbankan syariah di Indonesia dan beberapa ketentuan yang berkaitan dengan pembiayaan murabahah.

\section{Daftar Pustaka}

Ab. Ghani, Ab. Mumin \& Fadilah Mansor, 2006, Dinamisme Kewangan Islam di Malaysia. Kuala Lumpur: Universiti Malaya.

Al-'Imrâni. Al-'uqûd al-Mâliyah al-Murakkabah.

Al-Kasani, Bada'i al-Shana'i, jilid VII.

Al-Khin, Mustafa, Al-Fiqh al-Manhaji, 1989, Damaskus: Dar al-Qalam.

Al-Qazwini, Alkhafidhi Abi Abdillah Muhammad Ibni Yazid, Sunan Ibnu Majah, Juz 2. Darul Al-Fikr.

Ascarya, Akad \& Produk Bank Syariah, 2007. Jakarta: RajaGrafindo Persada. 
Ibnu Abidin, Muhammad Amin, 1992, Hasyiyah Radd al-Mukhtar Ala al-Durar al-Mukhtar: Syarh Tanwir al-Abshar fi Fiqh Madzab Imam Abu Hanifah al-Nu'man, Jilid V. Beirut: Dar al-Fikr.

Kalsum, Ummi, 2012, Analisis Moneter Islam dalam Sistem Perbankan Ganda di Indonesia. Jakarta: Ciputat Press.

Rahman, Afzalur, 1985, Economic Doctrines of Islam, Vol. III. Lahore Pakistan: Islamic Publications LTD.

Saeed, Abdullah, 2004, Menyoal Bank Syariah: Kritik atas Interpretasi Bunga Bank Kaum Neo-Revivalis. Jakarta: Paramadina.

Sakti, Ali Sakti, 2007, Analisis Teoritis Ekonomi Islam: Jawaban atas Kekacauan Ekonomi Modern. Jakarta: Paradigma \& Aqsa.

Sjahdeini, Sutan Remy, 2010, Perbankan Syariah Produk-produk dan Aspek-aspek Hukumnya. Jakarta: Jayakarta Agung Offset.

Widjaja Z, Wangsa, 2012, Pembiayaan Bank Syariah. Jakarta: Gramedia Pustaka Utama. 